\title{
A new species of Tanycarpa Förster (1862) (Hymenoptera, Braconidae: Alysiinae) from Itatiaia National Park, Rio de Janeiro, Brazil
}

\author{
P. C. M. Cerântola ${ }^{*}$, C. S. Souza-Gessner ${ }^{a}$ and A. M. Penteado-Dias ${ }^{b}$ \\ aPrograma de Pós-graduação em Ecologia e Recursos Naturais, Universidade Federal de São Carlos - UFSCar, \\ Rod. Washington Luís, Km 235, SP-310, CP 676, CEP 13564-905, São Carlos, SP, Brazil \\ ${ }^{b}$ Departamento de Ecologia e Biologia Evolutiva, Universidade Federal de São Carlos - UFSCar, Rod. Washington Luís, \\ Km 235, SP-310, CP 676, CEP 13564-905, São Carlos, SP, Brazil \\ *e-mail: paulacerantola@gmail.com
}

Received: March 6, 2015 - Accepted: June 15, 2015 - Distributed: August 31, 2016

(With 3 figures)

\begin{abstract}
This is the first description of a species of the genus Tanycarpa Förster (1862) for Brazil. Forty-eight specimens were collected in High Montane Dense Ombrophilous Forest area at National Park of Itatiaia, RJ, using four Malaise traps installed, respectively, at four different altitudes. This study is based on a description of two species of Tanycarpa from Colombia, Tanycarpa edithae and Tanycarpa sarmientoi, which are the only species of this genus recognized for the neotropics.
\end{abstract}

Keywords: new species, parasitoid, Tanycarpa, taxonomy.

\section{Uma nova espécie de Tanycarpa Förster (1862) (Hymenoptera: Braconidae: Alysiinae) do Parque Nacional do Itatiaia, Rio de Janeiro, Brasil}

\begin{abstract}
Resumo
Esta é a primeira descrição de uma espécie do gênero Tanycarpa Förster (1862) para o Brasil. Foram coletados 48 espécimes em uma área de Floresta Ombrófila Densa Alto Montana do Parque Nacional do Itatiaia, RJ, com o uso de quatro armadilhas Malaise instaladas, respectivamente, em quatro altitudes diferentes. Este trabalho foi baseado na descrição de duas espécies de Tanycarpa da Colômbia, Tanycarpa edithae e Tanycarpa sarimentoi, as únicas espécies desse gênero reconhecidas para a região Neotropical.
\end{abstract}

Palavras-chave: nova espécie, parasitoide, Tanycarpa, taxonomia.

\section{Introduction}

The Braconidae are the second largest family of Hymenoptera, within the superfamily Ichneumonoidea, with approximately 19,439 described species included in 46 recognized subfamilies (Yu et al., 2012); among these subfamilies, the Alysiinae are an easily distinguishable group by having exodont mandibles (Dix-Luna, 2009).

Alysiinae are a cosmopolitan subfamily, with more than 2,300 worldwide described species grouped in 104 genera (Yu et al., 2012), of which 41 were recorded in the New World (Wharton, 1994). The group is divided into two tribes, Dacnusini and Alysiini, which are separated by the absence (Dacnusini) or presence (Alysiini) of $r-m$ vein in the forewing (Wharton, 1980); both have approximately the same number of species, however Alysiini contains 31 of the 41 genera occurring in the New World (Wharton, 1994).

All Alysiinae are endoparasitoids cenobionts of ciclorraphous dipterous larvae (Griffiths, 1964; Wharton, 1997) and have as hosts specially species of Phoridae,

Drosophilidae and Tephritidae (Ovruski et al., 2000), Agromyzidae, Calliphoridae, Chloropidae, Muscidae and Ephydridae (Dix-Luna, 2009). The ciclorraphous flies can cause damage to certain crops; therefore the Alysiinae have been increasingly used in the biological control of pests in crops (Hendrikse et al., 1980), thus it is necessary to contribute to the knowledge of taxonomy and biology of this subfamily.

According to Dix-Luna (2009), the Alysiinae are still poorly studied in the Neotropical region. In Brazil, Arouca and Penteado-Dias (2004) and Arouca et al. (2004) reported the occurrence of several genera that already had been described occurring in other New World places as well as undescribed species (Arouca, 2005).

Tanycarpa Förster (1862) belongs to Alysiini tribe; it is a cosmopolitan group, where the major number of species (11 species) is found in East Palaearctic (Yu et al., 2012). It has 20 recognized species worldwide, of which 
four are distributed in Nearctic and only two occur in the Neotropics (Yu et al., 2012). Their hosts are ciclorraphous Diptera of the genus Drosophila, Mycetophila, Liriomyza and Scaptomyza (Yu et al., 2012).

Dix (2010) described the only two recognized species in the Neotropical Region, both from Colombia: Tanycarpa sarmientoi, collected between 2,100 and 2,905 meters of altitude, and Tanycarpa edithae, collected between 650 and 2,220 meters of altitude.

Wharton $(1980,1997)$ cited the occurrence of this genus in Brazil, but did not elaborate any description related to this record; therefore, this paper presents the first description of a new species of Tanycarpa from Brazil and aims to contribute to the knowledge of the Brazilian fauna of Alysiinae.

Studying the material from the DCBU collection of the Departamento de Ecologia e Biologia Evolutiva da Universidade Federal de São Carlos, SP, Brazil, from different localities we have registered several new species and new occurrence of species for Brazilian fauna (Pinto et al., 2014; Silva et al., 2014; Penteado-Dias, 2013; Araujo and Penteado-Dias, 2011, 2012; Sobczak et al., 2011; Castro et al., 2010, 2011; Arouca and Penteado-Dias, 2009; Loffredo and Penteado-Dias, 2008a, b).

\section{Material and Methods}

The material was collected at Itatiaia National Park (S $22^{\circ} 30^{\prime}$ and $22^{\circ} 33^{\prime} ; \mathrm{W} 42^{\circ} 15^{\prime}$ ' and $42^{\circ} 19^{\prime}$ '), a protected area of natural ecosystems situated within the Massif of Itatiaia, Serra da Mantiqueira; it is located between the States of Rio de Janeiro and Minas Gerais, comprising the following cities: Resende and Itatiaia, in Rio de Janeiro State, and Itamonte and Bocaina de Minas, in Minas Gerais State.

Samples were collected with the trap model proposed by Townes (1972) model and installed at different altitudes: 987 meters (S $22^{\circ} 26^{\prime} 16.8^{\prime \prime} \mathrm{W} 44^{\circ} 36^{\prime} 41.8^{\prime}$ '), 1,763 meters (S 22 22' 22.5' 'W 44 45' 19.7'), 2, 176 meters (S $22^{\circ} 21^{\prime}$ ' $50.6^{\prime \prime} \mathrm{W} 44^{\circ} 44^{\prime} 38.4^{\prime \prime}$ ) and 2,206 meters (S 22 $21^{\prime} 36.9^{\prime \prime}$ W 44 43' 56"); the Malaise at 987 meters of altitude is located in the city of Itatiaia, Rio de Janeiro State, and the traps installed above 1,000 meters of altitude are located in the city of Itamonte, Minas Gerais State. Samples were collected from July 2011 to June 2012, and at each altitude were obtained one sample per month.

In areas with altitude from 1,100 to 2,200 meters to North, the predominant type of vegetation is the Dense Ombrophilous High-Montane Forest (Santos, 1998), a variation of formation of the Atlantic Forest. The climate in the high mountain areas above 1,600 meters, according to Köppen standards is Cwb (mesothermal, with mild summer and rainy season in summer); the cold and dry period corresponds to months between May and August, with very common intense frosts and high rate of insolation and evaporation. Annual rainfall is about 2,400 $\mathrm{mm}$, and January has the greater intensity; the absolute maximum humidity occurs in December, with $83 \%$, and the minimum is in June, with $62 \%$ (Santos, 1998).

All the material were preserved in absolute alcohol $(100 \%)$; subsequently, the specimens were dried and mounted on entomological pins to be identified on genus level, based on Wharton (1997). The studied material is deposited in the Collection of the Department of Ecology and Evolutionary Biology at the Federal University of São Carlos (DCBU), SP, Brazil.

The description of this new species followed Dix (2010); the nomenclature of sculpture followed Harris (1979); the nomenclature of the veins and of the body morphology followed Sharkey and Wharton (1997); the measures of the specimens followed Goulet and Mason (2006).

The images were obtained in a scanning electron microscope FEI Quanta 250 in low vacuum with uncoated material, and with a digital camera Leica DFC295 attached to a stereomicroscope Leica M205_C using auto-montage software Leica Application Suite.

\section{Results}

Were found 48 specimens of genus Tanycarpa. The number of males and females found at each altitude are listed below:

.987 meters - zero specimens

. 1,763 meters - one male

.2,176 meters - 19 males and two females

. 2,206 meters - 23 males and three females

\subsection{Key to Neotropical species of Tanycarpa Förster}

1. Stigma 9.2 to 10 times longer than wider; length of the $r$ vein smaller or not exceeding the stigma wid th........................................................ 2

- Stigma narrow; r vein length larger than stigma width................................ sarmientoi

2(1). Scutellum densely setose; forewing with $3 \mathrm{RSb}$ vein 3.73 to 3.74 times longer than $3 \mathrm{RSa}$ vein; face 1.21 to 1.25 times wider than longer; clypeus brown T. edithae

- Scutellum with disperse setae; forewing with $3 \mathrm{RSb}$ vein 3.14 to 3.47 times longer than $3 \mathrm{RSa}$ vein; face 1.38 to 1.47 wider than longer; clypeus dark yellow (female) or yellow (male).....

T. itatiaia sp. $\mathbf{n}$.

Tanycarpa itatiaia sp. n.

(Figures 1 to 3 )

Holotype female (Figures 1a to 1e):

body length: $2.59 \mathrm{~mm}$.

forewing length: $2.88 \mathrm{~mm}$.

COLOUR. (Figures 1a, 1b and 1e). Mostly dark brown; face, front, vertex, temples and occiput dark brown; gena brown; clypeus and mandibles dark yellow (Figure 1e); labrum, labial and maxilar palp pale; antenna with scape 

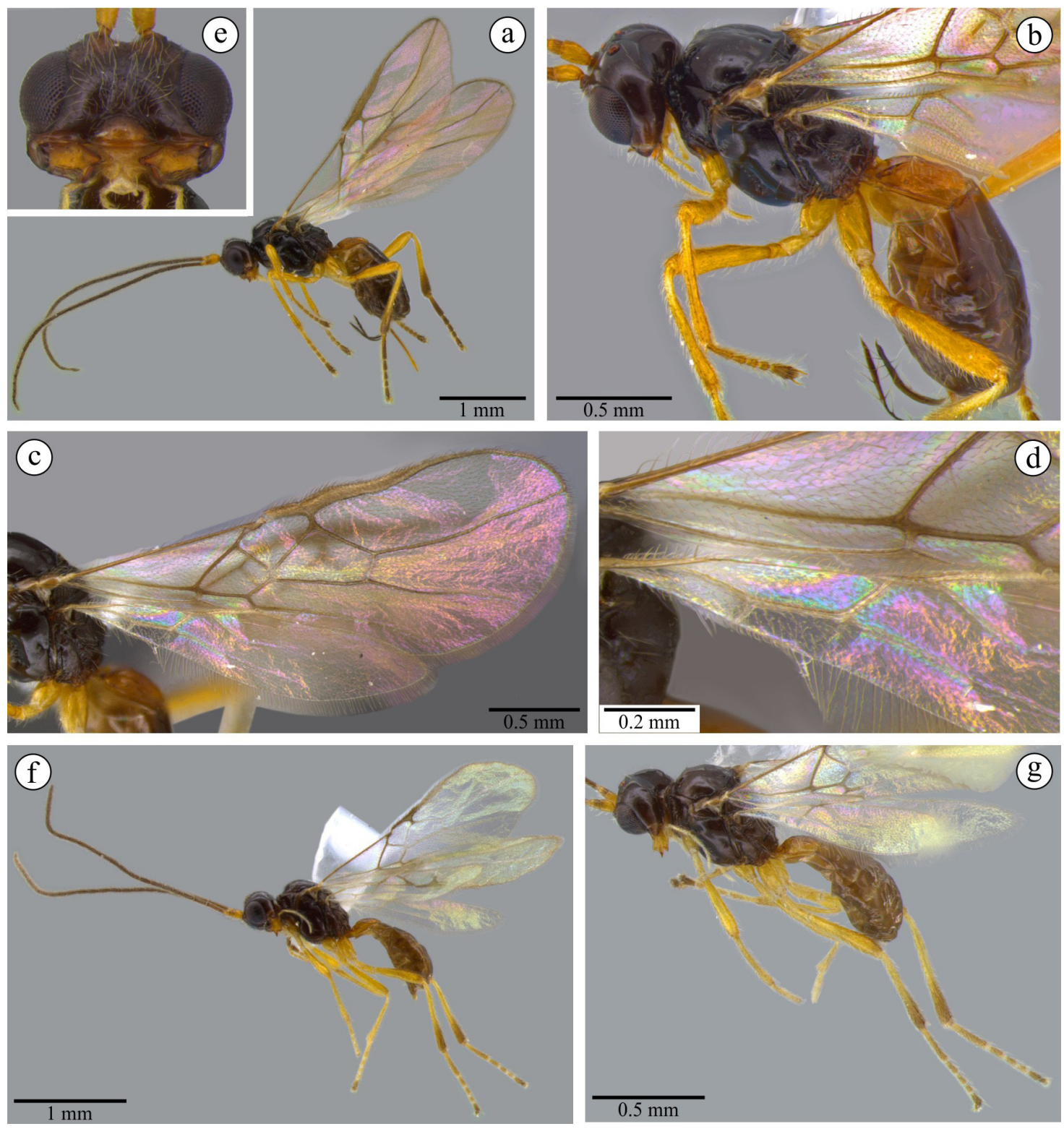

Figure 1. Tanycarpa itatiaia sp. n., holotype ${ }_{+}$. (a) habitus in lateral view; (b) habitus in dorsolateral view; (c, d) wings; (e) head in frontal view. Tanycarpa itatiaia sp. n., paratype ${ }^{\lambda}$; (f) habitus in lateral view; (g) habitus in dorsolateral view.

and pedicel yellow and flagellomeres brown; mesoscutum dark brown; wings hyaline; tergum I yellowish; remaining terga light brown; ovipositor sheaths brown; foreleg and midleg from coxae to $3^{\text {rd }}$ tarsomeres yellow, $4^{\text {th }}$ and $5^{\text {th }}$ tarsomeres yellowish brown; hindleg yellow from coxa to approximately $2 / 3$ of tibia, the remaining $1 / 3$ of tibia to the $5^{\text {th }}$ tarsomere yellowish brown.

HEAD. Clypeus smooth, densely setose, the lateral margin in contact with the tentorial pit which occupies about $1 / 3$ of the distance between the lateral margin of the clypeus and the eye (Figure 2a). Face 1.41 times wider than longer, smooth, polished, densely setose in the mid area and more disperse near the eyes (Figure 2a). Antennae with 25 segments. Front smooth, polished and without setae
(Figure 2b). Vertex smooth, polished and with disperse setae (Figure 2b). Eyes glabrous (Figure 2c). Malar space absent (Figure 2c). Mandible 1.87 times longer than its apical width, smooth, moderately setose with three teeth.

MESOSOMA. 1.26 times longer than height. Pronotum rugose and polished and with presence of pronope (Figure 2d). Mesoscutum smooth, polished, with disperse setae close to notauli; mid pit small and subcircular; notauli strongly crenulate, restrict to anterior slope of mesoscutum (Figure 2d). Scutellar sulcus 2.3 times longer than wider, with median carina present and laterally smooth (Figure 2e). Scutellum smooth, polished and with disperse setae (Figure 2e). Metanotum in dorsal view laterally crenulated with mid carina well developed (Figure 2e). Propodeum polished and 

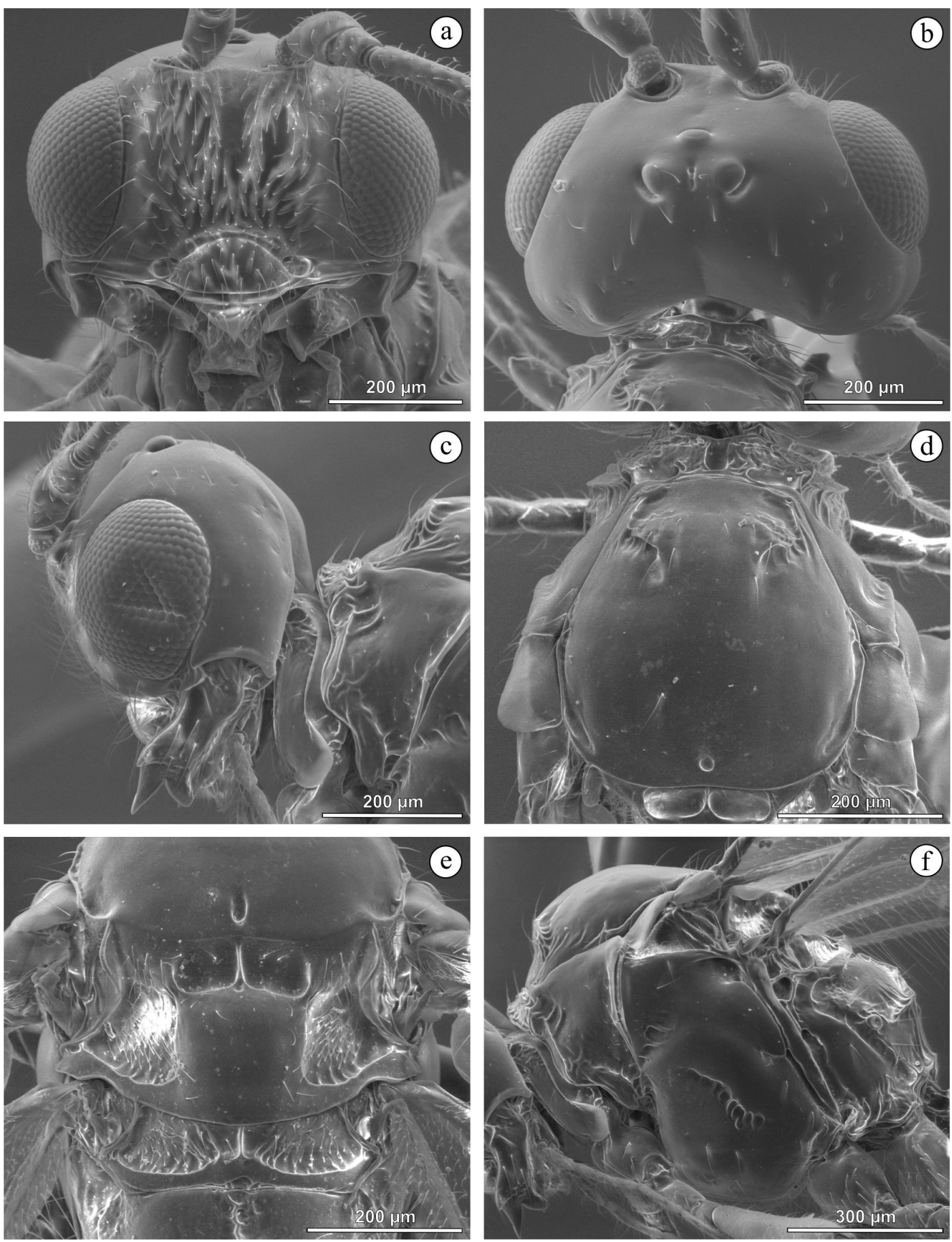

Figure 2. Tanycarpa itatiaia sp. n., paratypes $\$$. (a) head in frontal view; (b) head in dorsal view; (c) lateral view of head; (d) pronotum and mesoscutum in dorsal view; (e) scutellum in dorsal view; (f) mesopleurum in lateral view.

weakly rugose. Mesopleuron smooth and polished, with disperse setae on the ventral region; sternaulus strongly crenulated (Figure 2f). Metapleuron smooth and polished with disperse setae and a deep groove on the inferior margin (Figure 2f). Posterior femur 5.14 times longer than wider.

WINGS. (Figures 1c and 1d). Forewing: stigma 9.6 times longer than wider; $r$ vein shorter than the width of the stigma; $3 \mathrm{RSa} 1.05$ times longer than 2RS; 3RSb 3.3 times longer than $3 \mathrm{RSa}$; first subdiscal cell closed. Posterior wing: cu-a vein present; $\mathrm{m}$-cu weakly impressed (Figure 1d).

METASOMA. Tergum I polished and striated longitudinally; remaining tergum smooth and polished, with disperse setae and just along the division of terga 
(Figure 3a); ovipositor sheaths densely setose; ovipositor 0.8 times the length of mesosoma.

VARIATION. Body length: 2.06 to $2.83 \mathrm{~mm}$; forewing length: 2.3 to $2.98 \mathrm{~mm}$; face 1.39 to 1.47 times wider than longer; antenna 23 to 27 flagellomeres, the number of flagellomeres may vary between the antenna in the same individual; mandible 1,78 to 2.08 times longer than its apical width; mesosoma 1.24 to 1.4 times longer than higher; mid pit small and subcircular (Figure 3b), small and circular (Figure 3c) or elongated (Figure 3d); scutellar groove 2.25 to 2.5 times longer than its width; hind femur 4.9 to 5.3 times longer than wider; forewing: stigma 9.2 to 10 times longer than wider, length of the $r$ vein smaller or not exceeding the stigma width; $3 \mathrm{RSa}$ vein 1.05 to 1.2 times longer than $2 \mathrm{RS}$ vein; $3 \mathrm{RSb} 3.14$ to 3.47 times longer than $3 \mathrm{Rsa}$; ovipositor 0.8 to 1.05 times longer than mesosoma.

MALE. (Figures 1f and 1g). Similar to the female, except for: body length 1.82 to $2.02 \mathrm{~mm}$; forewing length 2.02 to $2.16 \mathrm{~mm}$; face 1.26 to 1.4 times wider than long; antenna with 24 segments; mandible 1.9 to 2.3 times longer than its apical width; mesosoma 1.33 to 1.44 times longer than high; scutellar sulcus 2 to 2.14 times longer than wide; hind femur from 4.67 to 5.1 times longer than wide; $3 \mathrm{RSa}$ vein 1 to 1.3 times longer than $2 \mathrm{RS}$; $3 \mathrm{RSb}$ vein 2.55 to 2.95 times longer than $3 \mathrm{RSa}$; body length 1.82 to $2.02 \mathrm{~mm}$; forewing length 2.02 to $2.16 \mathrm{~mm}$; color light brown; face, front, vertex, temple and occiput brown; gena light brown; clypeus and mandible yellow; antenna with scape and pedicel yellow to light yellow; mesoscutum brown to light brown; petiole yellowish and remaining terga light brown or metasoma entirely yellow; forelegs and middle legs light yellow from coxa to $3^{\text {rd }}$ tarsomere, $4^{\text {th }}$ and $5^{\text {th }}$ tarsomeres dark yellow; hind legs light yellow from coxa to approximately $2 / 3$ of the tibia, the remaining $1 / 3$ of tibia to the $5^{\text {th }}$ tarsomere dark yellow.

DIAGNOSIS. Similar to T. edithae (Dix, 2010) by the absence of malar space, the length/width proportion of the posterior femur, the broad stigma, the vein $r$ that is small than or equal to the width of stigma and the yellowish color of the tergum I. Similar to T. sarmientoi (Dix, 2010) by the proportion width/length of the face, the densely setose median area and laterally with dispersed setae, the hind wing m-cu vein is weakly impressed and the proportion of the ovipositor/mesosoma length. It differs from both species by having disperse setae on scutellum and the dark yellow color of clypeus (in T. edithae and T. sarmientoi the scutellum is densely setose and the clypeus is brown).
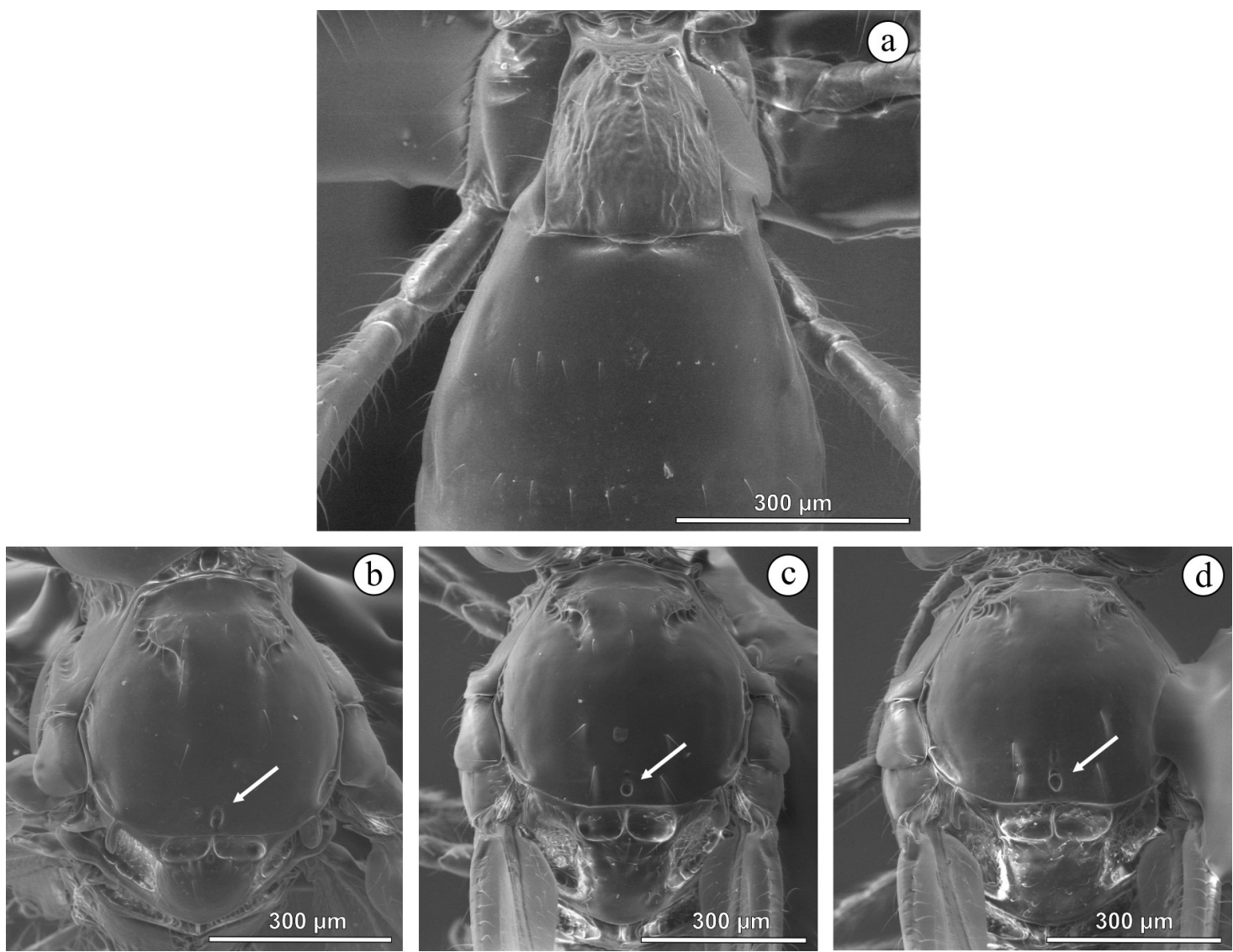

Figure 3. Tanycarpa itatiaia sp. n., paratypes q. (a) tergites I-III in dorsal view; (b-d) mesoscutum and scutellum showing mid pit in detail in dorsal view. 


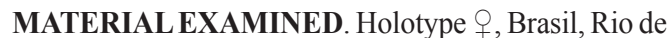
Janeiro, Itatiaia, Parque Nacional do Itatiaia, S $22^{\circ} 21^{\prime} 36.9^{\prime \prime}$ W 44 43' 56", 2,206 m, 07.XI.2011, Malaise trap, R. F. Monteiro col., DCBU 43,560. Paratypes, Brasil, Rio de Janeiro, Itatiaia, Parque Nacional do Itatiaia, Malaise trap, R. F. Monteiro col. S $22^{\circ} 22^{\prime} 22.5^{\prime \prime}$ W 44 45' 19.7', $1,763 \mathrm{~m}, 1$,, 22 .XII.2011, DCBU 58,080. S $22^{\circ} 21^{\prime} 50.6^{\prime \prime}$ W 44 44 ' 38.4 ', 2,176 m, 1ㅇ, 18.VIII.2011, DCBU 58,$079 ; 3$;, $07 . X I .2011$, DCBU 43,554, DCBU 58,081 and DCBU 58,082; 6 9 , 22.XII.2011, DCBU 43,558, DCBU 43,559, DCBU 58,102, DCBU 58,103, DCBU 58,104 and DCBU 58,105; 6ภ, 01.II.2012, DCBU 43,562, DCBU 58,085 , DCBU 58,086, DCBU 58,087, DCBU 58, 088 and DCBU 58,089; 19 and $1 \hat{\gamma}, 06$. III.2012, DCBU 43,553 and DCBU 43,561; 3ㅇ, 18.VI.2012, DCBU 34,604, DCBU 58,083 and DCBU 58,084. S $22^{\circ} 21^{\prime} 36.9^{\prime \prime} \mathrm{W} 44^{\circ}$ 43' 56", 2,206 m, 1ㅇ, 19.VII.2011, DCBU 58,090; 2 ㅇ, 07.XI.2011, DCBU 43,555 and DCBU 58,092; 6 ㅇ and 10, 22.XII.2011, DCBU 43,557, DCBU 58.097, DCBU 58,098 , DCBU 58,099, DCBU 58,100, DCBU 58,101 and DCBU 58,$096 ; 4$; , 01.II.12, DCBU 43,556, DCBU 58,093 , DCBU 58,094 and DCBU 58,095; 1 우 and $1 \hat{0}$, 06.III.2012, DCBU 58,091 and DCBU 43,563; 89 and

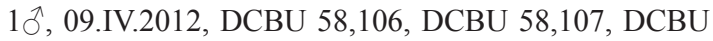
58,108 , DCBU 58,109, DCBU 58,110, DCBU 58,111, DCBU 58,112, DCBU 58,113 and DCBU 58,114.

ETYMOLOGY. The name of the species refers to the locality Itatiaia, where the specimens were collected.

\section{Acknowledgements}

We are grateful to the Conselho Nacional de Desenvolvimento Científico e Tecnológico (CNPq), Coordenadoria de Aperfeiçoamento de Pessoal de Nível Superior (CAPES), Fundação de Amparo à Pesquisa do Estado de São Paulo (FAPESP), and the Instituto Nacional de Ciência e Tecnologia dos Hymenoptera Parasitóides da Região Sudeste Brasileira (INCT- Hympar Sudeste) for financial support, to Itatiaia National Park for permitting the collection of material, and to Dra. Luciana Bueno dos Reis Fernandes for the ilustrations.

\section{References}

ARAUJO, C.R. and PENTEADO-DIAS, A.M., 2011. New species of Metopiinae (Hymenoptera, Ichneumonidae) from Brazil. Brazilian Journal of Biology $=$ Revista Brasileira de Biologia, vol. 71, no. 1, pp. 203-207. http://dx.doi.org/10.1590/ S1519-69842011000100029. PMid:21437419.

ARAUJO, C.R. and PENTEADO-DIAS, A.M., 2012. First record of Seticornuta Morley (Hymenoptera, Ichneumonidae, Metopiinae) from Brazil and description of a new species. Brazilian Journal of Biology = Revista Brasileira de Biologia, vol. 72, no. 2, pp. 414-418. http://dx.doi.org/10.1590/S1519-69842012000200025. PMid:22735152.

AROUCA, R.G., 2005. Taxonomia e diversidade dos Alysiinae (Hymenoptera: Braconidae) Neotropicais, com ênfase na fauna da Mata Atlântica, Brasil. São Carlos: Universidade Federal de São Carlos, 111 p. Masters Dissertation.
AROUCA, R.G. and PENTEADO-DIAS, A.M., 2004. First record of Phaenocarpa Foerster (Hymenoptera: Braconidae: Alysiinae) from Brazilian Atlantic Forest. Entomotropica, vol. 19, no. 3, pp. 44-46.

AROUCA, R.G. and PENTEADO-DIAS, A.M., 2009. First record of four Alysiinae species (Hymenoptera, Braconidae) from Brazil. Brazilian Journal of Biology $=$ Revista Brasileira de Biologia, vol. 69, no. 4, pp. 1209-1210. http://dx.doi.org/10.1590/S151969842009000500030 . PMid:19967197.

AROUCA, R.G., PENTEADO-DIAS, A.M. and ACHTERBERG, C.V., 2004. A new species of Phaenocarpa Foerster (Hymenoptera: Braconidae: Alysiinae) from Brazil. Zoologische Medelingen Leiden, vol. 78, no. 5, pp. 123-130.

CASTRO, C.S., NUNES, J.F. and PENTEADO-DIAS, A.M., 2010. Two new species of Pedinotus Szépligeti 1902 (Hymenoptera: Braconidae: Doryctinae) from the Savannah in São Paulo state, Brazil. Brazilian Journal of Biology $=$ Revista Brasileira de Biologia, vol. 70, no. 4, pp. 1103-1107. http://dx.doi.org/10.1590/ S1519-69842010000500028. PMid:21180921.

CASTRO, C.S., NUNES, J.F. and PENTEADO-DIAS, A.M., 2011. A new species of Heredius Marsh 2002 (Hymenoptera: Braconidae: Doryctinae) from Brazil. Brazilian Journal of Biology $=$ Revista Brasileira de Biologia, vol. 71, no. 1, pp. 175-177. http:// dx.doi.org/10.1590/S1519-69842011000100025. PMid:21437415.

DIX, O., 2010. Cuatro especies nuevas de Alysiinae (Hymenoptera: Braconidae) y registro nuevo para Colombia. Revista Colombiana de Entomologia, vol. 36, no. 2, pp. 304-314.

DIX-LUNA, O.J., 2009. Sinopsis de las especies de la subfamilia Alysiinae (Hymenoptera: Braconidae) em Colombia. Bogotá: Science College, Department of Biology, Universidad Nacional de Colombia, 248 p. Masters Dissertation.

GOULET, H. and MASON, P.G., 2006. Review of the Nearctic species of Leiphron and Peristenus (Hymenoptera: Braconidae: Euphorinae) parasitizing Lygus (Hemiptera: Miridae: Mirini). Zootaxa, vol. 1323, pp. 1-118.

GRIFFITHS, G.C.D., 1964. The Alysiinae (Hymenoptera: Braconidae) parasites of Agromyzidae (Diptera). I. General questions of taxonomy, biology and evolution. Beiträge zur Entomologie, vol. 14, pp. 823-914.

HARRIS, R.A., 1979. A glossary of surface sculpturing. Occasional Papers in Entomology, vol. 28, pp. 1-31.

HENDRIKSE, A., ZUCCHI, R., LENTEREN, J.C.V. and WOETS, J., 1980. Dacnusa sibirica Telenga y Opius pallipes Wesmael (Hym., Braconidae) in the control of the tomato leafminer Liriomyza bryoniae Kalt. Zurich: IOBC-WPRS, pp. 83-98. Bulletin IOBC/ WPRS, no. 3.

LOFFREDO, A.P. and PENTEADO-DIAS, A.M., 2008a. First record of Schizopyga Gravenhorst (Hymenoptera, Ichneumonidae, Pimplinae) from Brazil and a description of a new species. Brazilian Journal of Biology $=$ Revista Brasileira de Biologia, vol. 68, no. 2, pp. 457-458. http://dx.doi.org/10.1590/S151969842008000200034. PMid:18660981.

LOFFREDO, A.P. and PENTEADO-DIAS, A.M., 2008b. First record of Ticapimpla vilmae Gauld, 1991 (Hymenoptera, Ichneumonidae, Pimplinae) from Brazil. Brazilian Journal of Biology $=$ Revista Brasileira de Biologia, vol. 68, no. 4, pp. 911. http://dx.doi.org/10.1590/S1519-69842008000400032. PMid:19197515. 
OVRUSKI, S., ALUJA, M., SIVINSKI, J. and WHARTON, R., 2000. Hymenopteran parasitoids on fruit-infesting Tephritidae (Diptera) in Latin America and the southern United States: diversity, distribution, taxonomic status and their use in fruit fly biological control Integrated Pest. Management Review, vol. 5, pp. 81-107.

PENTEADO-DIAS, A.M., 2013. New species of the genus Dentigaster Zettel (Hymenoptera, Braconidae, Cheloninae) from Brazil. Brazilian Journal of Biology $=$ Revista Brasileira de Biologia, vol. 73, no. 2, pp. 409-412. http://dx.doi.org/10.1590/ S1519-69842013000200023. PMid:23917570.

PINTO, A.A., TELES, B.R. and PENTEADO-DIAS, A.M., 2014. First Report of Phanerotoma bennetti Muesebeck (Hymenoptera, Braconidae, Cheloninae) Parasitizing Hypsipyla grandella (Zeller) and Hypsipyla ferrealis Hampson (Lepidoptera, Pyralidae) in Crabwood in Brazil. Brazilian Journal of Biology $=$ Revista Brasileira de Biologia, vol. 74, no. 1, pp. 264-265. http://dx.doi. org/10.1590/1519-6984.23812. PMid:25055113.

SANTOS, R.F., 1998. Mapeamentos temáticos do Parque Nacional do Itatiaia. Brasília: IBAMA/FBDS, pp. 40-48.

SHARKEY, M.J. and WHARTON, R.A., 1997. Morphology and terminology. In: R.A. WHARTON, P.M. MARSH and M.J. SHARKEY, eds. Manual of the New World Genera of the Family Braconidae (Hymenoptera). Washington: International Society of Hymenopterists, pp. 85-118.

SILVA, R.B., CRUZ, I. and PENTEADO-DIAS, A.M., 2014. First report of Dolichozele koebelei Viereck, 1911 (Hymenoptera: Braconidae) on larvae of Spodoptera frugiperda (J. E. Smith,
1797) (Lepidoptera: Noctuidae) in maize (Zea mays L.) under different cropping systems. Brazilian Journal of Biology $=$ Revista Brasileira de Biologia, vol. 74, no. 3, suppl. 1, pp. 218-222. http:// dx.doi.org/10.1590/1519-6984.00413. PMid:25627388.

SOBCZAK, J.F., LOFFREDO, A.P. and PENTEADO-DIAS, A.M., 2011. Description of the male of Hymenoepimecis veranii Loffredo \& Penteado-Dias 2009 (Hymenoptera, Ichneumonidae, Pimplinae). Brazilian Journal of Biology = Revista Brasileira de Biologia, vol. 71, no. 1, pp. 225-226. http://dx.doi.org/10.1590/ S1519-69842011000100035. PMid:21437425.

TOWNES, H.A., 1972. A light-weight Malaise trap. Entomological News, vol. 83, pp. 239-247.

WHARTON, R.A., 1980. Review of the Nearctic Alysiini (Hymenoptera: Braconidae) with discussion of generic relationships within the Tribe. 104 p. Berkeley: University of California Press. University of California Publications in Entomology, no. 88.

WHARTON, R.A., 1994. New genera, species, and records of New World Alysiinae (Hymenoptera: Braconidae). Proceedings of the Entomological Society of Washington, vol. 96, pp. 630-664.

WHARTON, R.A., 1997. Alysiinae. In: R.A. WHARTON, P.M. MARSH and M.J. SHARKEY, eds. Manual of the New World Genera of the Family Braconidae (Hymenoptera). Washington: International Society of Hymenopterists, pp. 85-118.

YU, D.S., ACHTERBERG, C.V. and HORSTMANN, K., 2012. World Ichneumonoidea 2011: taxonomy, biology, morphology and distribution. Vancouver: Taxapad. CD version. 